\title{
The case of an operetta being banned in Hungary in 1928, viewed in the mirror of contemporary press sources
}

\author{
Emese Lengyel*
}

Doctoral School of Literary and Cultural Studies, Institute of Library and Media Studies, University of Debrecen, Hungary

\section{ORIGINAL RESEARCH PAPER}

Received: December 12, 2020 • Accepted: September 20, 2021

Published online: November 15, 2021

(C) 2021 The Author(s)

\section{ABSTRACT}

In May 1928, the Andrássy Street Theatre in Budapest planned to re-stage a one-act operetta play titled The First Kiss is Mine. Its libretto was written by Jenő Heltai, and the music was composed by Albert Szirmai. The new performance started out as a resounding success. But, referring to current laws on public morality, Ministry of Interior department in charge of controlling public and cultural programmes banned the play without delay, on 18 May, and Minister of the Interior, Béla Scitovszky ordered an investigation into the matter.

People referred to the event as a scandal, and the press spoke of it as an absurdity, as the theatre enterprise was endangered by the resulting loss in income. After the ban, the actors were only allowed to perform the play for a commission sent from the Ministry of Interior, and finally, on 22 May, Scitovszky permitted the program after all, with some minor changes. In my study, I reconstruct and present the events of these few days with the help of contemporary journalistic sources (reports, interviews, etc.) - Budapesti Hírlap, Esti Kurir, Magyar Hírlap, Magyarország, Pesti Hírlap, Pesti Napló, Újság, 8 Órai Újság -, the circumstances of the prohibition, the protest and opinion of the playwrights, the position of the commission, the performance for the commission, and the background of the permission for the new performance.

\section{KEYWORDS}

Andrássy street theatre, protection of morals, Jenő Heltai, operetta, Albert Szirmai, journalistic sources

\footnotetext{
*Corresponding author. E-mail: lengyelemese1@gmail.com
} 
"In the history of Hungarian acting, it was a common phenomenon that the authorities would ban plays that they did not like - for whatever reason." In May 1928, this fate finally reached the one-act operetta play ${ }^{2}$ titled Enyém az elsö csók [The First Kiss is Mine]. Finally, we say, since it had already played ${ }^{3}$ twenty-one years earlier in 1907 as Jus primae noctis [Lord's Right] with huge success. The libretto had been written by Jenö Heltai (1871-1957), ${ }^{4}$ the music had been composed by Albert Szirmai (1880-1967), ${ }^{5}$ both internationally acknowledged playwrights (Szirmai is often mentioned as Sirmay or Szirmay in non-Hungarian sources).

Before describing reviews written after the ban in 1928, I would like to highlight that after the premiere in 1907 we read the following in the magazine Az Ujság [The Newspaper], authored by one h.a., "[...] The program of the opening evening was quite diverse. [...] I really liked Jeno" Heltai's operetta, Jus primae noctis [...] The music of the operetta and the couplets is absolutely insignificant, I shouldn't even mention it. [...]"6 As a preliminary point, I would add that a few decades later, critiques praise the work of both of them.

Such a temporary ban on the performance by the Andrássy Street Theatre ${ }^{7}$ was possible because of a Circular Decree of the Ministry of the Interior in force at the time (see below). Besides provoking a broad-ranging outcry, the incident also caused serious financial loss to the theatre. Hungarian playwrights expressed their concerns regarding the procedure and the way in

${ }^{1}$ Banned plays. In: Encyclopaedia of Hungarian Theatre Arts Volume 1 Ed. Aladár Schöpflin. Budapest: National Actors Association and Pension Institute 1929, 189.

${ }^{2}$ It is not among the aims of this story to elaborate on operetta playing after the break-up of the Monarchy. On this topic in general see, among others, András Batta: Magyar operett a Monarchia széthullása után. Magyarország a XX. században III. kötet. Kultúra, müvészet, sport és szórakozás [Hungarian Operetta after the Break-up of the Monarchy. In Hungary in the XX. Century, vol. III. Culture, Art, Sport and Entertainment] Ed. István Kollega- Tarsoly. Szekszárd: Babits. 1998, 515-517.

3"The Hungarian Cabaret Theatre opens on Friday, the 11th of this month [...] three one-act operettas are to be performed: a witty operetta by Heltai-Szirmai, Jus primae nocti;s, a satire by István Szomaházy titled A trónörökös [The Heir], and a funny cabaret piece by Ferenc Molnár Drágaság [Precious]. [...]." The Opening of the Modern Theatre. Pesti Hirlap, vol. XXIX, issue 240. (9 October 1907), 7. See for example The Opening of a Modern Theatre... Pesti Napló. vol. LVIII, issue 240. (9 October 1907), 16. About the History of the Cabaret in Pest see Tibor Bános, A pesti kabaré [Cabaret in Pest]. In: Magyar Színháztörténet 1873-1920 [Hungarian Theatre History 1873-1920]. Ed. Tamás Gajdó. Budapest, Magyar Könyvklub - OSZMI 2011, 656-676.

${ }^{4}$ Jenő Heltai. Magyar Színházmüvészeti Lexikon. Ed. György Székely. Budapest: Akadémiai Publisher 1994, 297. For more on his work, see Zsolt Györei: Heltai Jenö drámai életmüve [The Dramatic Works of Jenö Heltai]. Budapest, L 'Harmattan, 2005. (He defended his $\mathrm{PhD}$ thesis of the same title in 2002. This volume is an edited version of that thesis.

${ }^{5}$ Albert Szirmai. Magyar Színházmüvészeti Lexikon., op. cit., 767.

${ }^{6}$ A Modern Színház megnyitása [The Opening of the Modern Theatre]. Az Újsag vol. V., issue 242. (12 October 1907) 12.

7"First, it ran as the Modern Theatre Cabaret between 1907 and 1908, with the direction of Sándor Faludi. Between 1908 and 1913 it the cabaret was run by Endre Nagy under the name Modern Theatre, between 1913 and 1925, it was Vilma Medgyaszay's cabaret, between 1916 and 1916 it was called Modern Cabaret Stage with the direction of Artur Bárdos; it was closed until the end of 1927, then it was reconstructed following to the plans of Rezsö Herquet, and was re-opened with the name Andrássy Street Theatre with the last huge success of the Downtown Theatre by Artur Bárdos, and was to remain the only cabaret until 1933. In 1920, it was taken over by Unio Rt, with Tamás Emőd as director; in 1925, the director was Elemér Wertheimer, the dramaturg was Lóránd Barnabár, and the music director was Dezső Losonczy; in the year of 1924/25 and after 1937, it was the chamber theatre of the National Theatre." Andrássy Street Theatre. In $A$ fóvárosi kisszínházak müsora. A Tháliától a felszabadulásig 1904-1944 (Adattár). [The Program of the Small Theatres in the Capital. From Thalia until the liberation 1904-1944] Ed. Ágnes Alpár. Budapest: Institute of Hungarian Theatre, 1974, 22.; See Andrássy Street Theatre. Magyar Színházmüvészeti Lexikon., op. cit., 26-27. 
which it was executed. After the premiere on 16 May, ${ }^{8}$ the decision came into force on 18 May. It was finally withdrawn by the Minister of Interior Béla Scitovszky ${ }^{9}$ on 22 May.

In this study, I undertake to reconstruct and present the history of the ban by contextualizing contemporary articles. ${ }^{10}$ I have selected 21 articles as primer source for my study, which were published between 17 May 1928 and 23 May 1928 in the columns of papers and magazines such as the Budapesti Hírlap, Esti Kurir, Magyar Hírlap, Magyarország, Pesti Hírlap, Pesti Napló, Újság, and 8 Órai Újság; as well as Circular Decree no. 151,000 of 1927 of the Minister of the Interior on the protection of public morality. ${ }^{11}$ Further press materials - which were published in May and June in the same year - I used as a secondary source. An additional aim is to discover more sources connected to the case, since texts in this study were chosen from dozens of written sources and articles. ${ }^{12}$

First we shall focus on the articles about the news of the re-staging, then we shift our attention to the circular decree about the protection of public morality. Next, I selected some articles from the press sources from 19 May, then I shall present the role and actions of the Association of Hungarian Playwrights in the case in a separate part. In the following section I unravel the details of the permission, including the circumstances of the performance for the committee of the Ministry of Interiors, then we examine another case strongly connected to this topic, moving on to discussing the terms of the renewed permission, and finally discuss the press sources which present the problem of theatre censure connected to Enyém az elsó csók.

\title{
REPORT ON THE PERFORMANCE
}

Hungarian literary historian Zsolt Györei wrote about the plays of Heltai. In the chapter Középkor és reneszánsz [The Middle Ages and the Renessaince] he elaborated on the operetta titled Jus Primae Noctis:

\begin{abstract}
We stopped on this short, humorous work almost exclusively for the sake of completion. Its topic relates it to Heltai's never-fading interest in medieval times without telling anything more about this interest. The Middle Ages merely serve as the obligatory background to the basic idea, which is imaged on the stage with flashy ornaments. The selection of poems and prose do not serve to confront two value systems, but, thanks to the music of Albert Szirmai, they color it with songs like in an operetta $[\ldots]^{13}$
\end{abstract}

${ }^{8}$ Ibid., 37.

${ }^{9}$ Béla Scitovszky (1878-1959) Minister of Interior in the Bethlen government from 15 October 1926 to 24 August 1931. For more on this, see: Béla Scitovszky. In Magyar Életrajzi Lexikon 2. [Hungarian Encyclopaedia of Biographies vol 2] Budapest: Akadémiai Publisher, 1982, 608.

${ }^{10}$ In the original Hungarian I cite the articles using contemporary spelling. However, wherever I found it warranted, I left the original highlights in bald or italic print.

${ }^{11}$ Circular Decree no. 151,000 of 1927 of the Minister of the Interior on the protection of public morality. Magyarországi Rendeletek Tára [Archive of Hungarian Decrees], 1923, vol 52. Hungarian Ministry of Interior 1924, 185-187.

${ }^{12}$ The study was written as a part of the research project which deals with the composer Albert Szirmai and his colleagues through press sources. (Supported by the National Cultural Fund of Hungary.)

\section{n<a}

${ }^{13}$ Györei, cit., 122. 
The complication was caused by the plot of the play, more precisely its libretto. Consequently, we cannot omit to offer a detailed description of the operetta. For this I used various articles as a basis. News of the oncoming premiere was reported, among others, in Esti Kurir ${ }^{14}$ and 8 Órai Újság. ${ }^{15}$ This time I picked from articles published on 17 May.

The question is how did Enyém az elsö csók get from Jenő Heltai to Jenő Heltai? This sentence is no typo - the history of the creation of this one-act play is also of interest. "There were so many great burlesques, comedies and scenes performed at that time from which no single line has been left for posterity" ${ }^{\prime 6}$ - indeed, the libretto of this play, performed in 1907, has also not survived. It is said that Heltai dictated the libretto to the dramaturgy director in an hour by heart, and the music was written in a night with an unknown co-author.

The small Andrássy Street Theatre - as we reported - give a reprise program and tonight it performs Heltai-Szirmai's operetta Enyém az elsö csók, which was performed twenty years ago on the same stage at the time of the theatre's opening with Sándor Faludy as director, Albert Szirmai as music director Ferenc Molnár and Jenő Heltai in charge of dramaturgy.

At that time, it was common practice among composers and playwrights that they did not write down their plays, but invited a bunch of actors for a rehearsal, talked together and formed the play as a joint effort. Many great burlesques, comedies, and scenes were performed from which not a single line has been left for posterity.

This is also how Enyém az elsó csók was written, which bore the title Jus primae noctis at the time $[\ldots]^{17}$

[...] Twenty years have passed since then and Elemér Wertheimer, director of the Andrássy Street Theatre thought that he would a reprise program, and collect all those treasures which had been thrown away over the previous twenty years. During the related discussions it occurred to Lóránd Barabás, dramaturge of the theatre, that Jus primae noctis should also be among the plays revived and performed, so he went to Jenő Heltai to ask for the manuscript of the play.

Heltai scratched the bank of his head and said:

'We have a huge problem, my friend,' he said, 'because although the play was showing for several months but we never had a libretto.'

'Maybe somehow?...' - begged the dramaturge.

'We can try', said Heltai and he dictated the whole play by heart in an hour.

\footnotetext{
${ }^{14}$ How did Enyém az első csók get from Jenő Heltai to Jenő Heltai. Esti Kurir. vol VI issue 112 (17 May 1928$) 11$.

${ }^{15}$ Premiere in Andrássy Street Theatre. 8 Órai Újság. vol XIV issue 112 (17 May 1928) 9.

${ }^{16}$ How did. ..., cit., 11.

${ }^{17}$ I have already mentioned above that we can read about the 1907 premiere in works about the history of the cabaret in Pest, since it was performed at the opening evening of the Modern Cabaret Theatre: "[...] Sándor Faludi, younger son of Gábor Faludy opened an »opponent cabaret« on 11 October 1907 at Andrássy street 69 under the name of Modern Cabaret Theatre on the ground floor of the Fine Art Council's palace built in 1871, with the help of his father. [...] He left the music direction to the twenty-two-year-old Albert Szirmai, who was a student of János Koessler at the Music Academy, then for a short time he worked as a tutor at the Folk Theatre Comedy Opera. Szirmai's lyrical and grotesque melodies attracted attention already in the first programs of the Bonbonniere. What Molnár, Heltai and Szirmai provided was just a little bit less than the audience could see in Endre Nagy's cabaret. In Bonbonniere, they talked and sang about the topics that were interesting for the everyday men. [...]" Bános, cit., 662.
} 
Now they had the play, but they did not have the music. So one night the two composers, Heltai and Albert Szirmai sat down and composed the music [...].

So after an hour and a night of work, Enyém az elsö csók was written again, in which the main character, once portrayed by unforgettable Antal Nyárai, ${ }^{18}$ was now played ${ }^{19}$ by Márton Rátkai. ${ }^{20}$

Applause, success, popularity. The next report also begins with reviving reception of the performance from twenty years before. But we can learn more details about the cast, and it praises the leaders of the theatre company:

[...] It was a great idea to bring this appealing and joyful operetta by Jenő Heltai and Albert Szirmai, which has the telling title Enyém az első csók back to the stage. With three great roles, it gives a great opportunity to three great actors to entertain the audience for 45 minutes by singing, dancing and joyful playing. These three roles are played by Márton Rátkai (the lord), Böske Tóth ${ }^{21}$ (the lady), and Irén Biller $^{22}$ (the bride waiting for the first kiss). All three acting performances are first-class: funny, witty, fine, and thoughtful operetta playing. [...] Ödön Faragó ${ }^{23}$ is a first-class director and actor; and directors Elemér Wertheimer and Lóránd Barnabás, as representatives of good taste, provide a decent and yet funny tone to the cabaret. ${ }^{24}$

\section{ABOUT THE PROTECTION OF PUBLIC MORALITY}

Hungarian Minister of Interior Béla Scitovszky issued a circular decree to protect public morality, which lays down the tasks connected to plays and other performances. The protection of morals and taste is the duty of the police authorities.

In order to stop the demoralizing effects of this harmful process and to protect the morality of Hungarian society - in addition to the previous regulations - I order the followings:

1 st $\S$. Police authorities are obliged to supervise every public stage and other performance, attraction and form of entertainment with a view to the presence of vice to a heightened extent. Furthermore, with actions provided by law according to 7th $₫$ of article XXI of 1881, point d) and 90.089/1919. B. M. [Ministry of Interior] (Archive of Hungarian Decrees vol 1919. 1092. o.), article 64.573/1901. B. M. (Archive of Hungarian Decrees volt 1901. p. 489) and article 229.230/1925. B. M. (Archive of Hungarian Decrees vol 1925 p. 267) and other regulations, they are obliged to stop any event that is against good morals due to its topic or the behaviour of the performers, and all public dances which

\footnotetext{
${ }^{18}$ In the article it is Nyáray. Antal Nyárai (1868-1920). See Antal Nyárai. Magyar Színházmüvészeti Lexikon vol III. Ed. Aladár Schöpflin. Budapest, National Actors' Association and Pension Institute 1930, 382-283.

${ }^{19}$ How did. .., cit., 11.

${ }^{20}$ Márton Rátkai (1881-1951) About his career, see Márton Rátkai. Magyar Színházmüvészeti Lexikon., cit., 641-642.; Zsigmond Móricz (1929): Márton Rátkai. Nyugat. vol XXII issue 1.; Péter Molnár Gál (2006): Márton Rátkai. Mozgó Világ [Moving World] vol XXXII issue 9. 121-125.

${ }^{21}$ Böske Tóth (1896-1979); for more details about her roles and life see Böske Tóth. Magyar Színházmüvészeti Lexikon., cit., 807.

${ }^{22}$ Irén Biller (1876-1958) about her career in more detail see Irén Biller. Magyar Színházmüvészeti Lexikon., cit., 95.

${ }^{23}$ Ödön Faragó (1876-1958) actor, director, theatre director. Ödön Faragó. Magyar Színházmüvészeti Lexikon., cit., 201.

${ }^{24}$ Premiere. ., cit., 9.
} 
are offend public morality or good taste. Companies with permission and directors of each performance are obliged to provide the chance for the representatives of the highest police authorities in charge to supervise performances, etc. The Minister of Interior as the highest anti-vice authority is allowed to practice supervision anytime through his representatives in lieu of the police authorities. ${ }^{25}$

[...] Acts listed in the 1 st point of the $3 \mathrm{rd} \S$ are considered to be transgressions even if they are not addressed to anyone or are not committed with offensive intent. Procedures following these transgressions pertain to administrative authorities as the police criminal court, while in the area of the Hungarian royal court, these pertain to the Hungarian royal state police. ${ }^{26}$

According to the circular decree, the fate of each performance depended on the police, and this regulation about the protection of public morality is definitely strict, it does not leave very much space for the practitioners of the performing arts. Hungarian playwrights and theatre managers raised their voice many times against the restrictions.

\section{NEW DAY NEW BAN - 19 MAY 1928}

The press reported the ban immediately on 19 May. They were baffled by the case, but the reporters tried to give detailed information. By way of illustration, I chose articles from the Ujság (Tilos az Enyém az elsö csók elóadása) [The First Kiss is Mine is Banned] ${ }^{27}$ the Pesti Hírlap (Húsz év elótt száz elóadás ma - betiltás) [A Hundred Performances Twenty Years Ago - Today, a Ban], ${ }^{28}$ and Pesti Napló (A rendórség betiltotta az Andrássy úti Színház Heltai-Szirmai operettjét. Bezzegh-Huszágh fókapitány nyilatkozik - Tiltakoznak az irók) [Police Bans Heltai-Szirmai Operetta in Andrássy Street Theatre. Commissioner Bezzegh-Huszágh Makes Statement - Playwrights Protest]. ${ }^{29}$

The article published in the Újság calls attention primarily to the absurdity of the decree, but it also details the stages of the case: 1 . performance on Wednesday, 16 May - success; 2. report violation of public morality; 3. decision - play banned with immediate effect; 4 . on Friday, 18 May the play cannot be performed; 5 . appeal of the theatre management; 6 . meanwhile, the theatre management is looking for an alternative - perform another play.

[...] The Ministry of Interior's department responsible for morality proved again that it does not allow any transgression of good morals. It pounced with enormous rigor in order to stop debauchery which could cause unpredictable damages - in the eyes of the Ministry of Interior.

The rigor of the Ministry of Interior regarding actions offensive to good morals has reached the Andrássy Street Theatre. This theatre, which selects its program following artistic and literary criteria

\footnotetext{
${ }^{25}$ Circular Decree no. 151,000 .., cit., $185-186$.

${ }^{26}$ Ibid., 186-187.

${ }^{27}$ Tilos az Enyém az első csók elóadása [Performance of Enyém az elsö csók is banned]. Újság. vol IV issue 113 (19 May 1928) 11.

${ }^{28}$ Húsz év előtt száz előadás, ma - betiltás. [A Hundred Performances Twenty Years Ago, Today a Ban] Pesti Hírlap. vol L issue 113 (19 May 1928) 10.

${ }^{29}$ A rendőrség betiltotta az Andrássy úti Színház Heltai-Szirmai operettjét. Bezzegh-Huszágh fókapitány nyilatkozik Tiltakoznak az írók [Police Bans Heltai-Szirmai Operetta in Andrássy Street Theatre. Commissioner Bezzegh-Huszár Makes Statement - Playwrights Protest]. Pesti Napló. vol LXXIX issue 113 (19 May 1928) 11.
} 
for the whole season and represents the best qualities of Hungarian cabaret, has decided now, at the end of the season, that it would produce a reprise of the successful plays and individual scenes performed ever since its foundation. [...]

At that time, Jus primae noctis was not seen as a criminal attempt against good morals, today it is said to be unbearably disgusting by the event supervisory department of the Ministry of Interior which surely knows what it is doing, as it has to evaluate Bakerian nudity in the world of artistically undressed dancing Greeks in its own special way. [...]

The reprise of the play was performed on Wednesday with huge success. No one was shocked by it. At the same time, the Ministry of Interior deems to have detected a criminal attempt against good morals and has begun to produce case files.

On Friday at $12 \mathrm{pm}$ the files arrived in their final form to the director of the Andrássy Street Theatre, Elemér Wertheimer. In the decision, chief advisor Páll says that based on the report of the even supervisory department of the Ministry of Interior, vice-commissioner Károly Andréka bans the performance of the operetta titled Enyém az elsö csók with immediate effect. At the same time, he tells him that he can appeal against the decision only outside the property.

[...] The director has claimed that the Heltai-Szirmai operetta could be performed without any concerns twenty years ago because it has an absolute artistic and literary value and it cannot be an object of complaint today either, when plays with artistic nudity and erotic effects are in the programs of orpheums, music halls, and even theatres. [...] Since then, Enyém az elsö csók will be removed from the theatre's program, and it will be replaced by the one-act Szövetségesek [Allies] starring Pufi Huszár. ${ }^{30}$

Besides writing the same panels and information, Pesti Hirlap ${ }^{31}$ focused on the "measures" taken by director Elemér Wertheimer. The article described that it had never occurred to the directors for a moment that the performance would face these kinds of obstacles:

[...] the topic, which the operetta dealt with without any obscenity, was considered to be against public morality by today's police, because on Friday at noon, police advisor Páll told the director of the Andrássy Street Theatre that based on the report of the event supervisory department of the Ministry of Interior, vice-commissioner Andréka ordered the play to be removed from the program.

Director Wertheimer, who did not expect that a play that had seen a hundred performances twenty years previously would be "against public morality", went to the headquarters and told them that he saw the ban as a violation of the freedom of art and literature. They acknowledged the director's appeal, but he was told that the play could not be performed during the period of the appeal either, so the Andrássy Street Theatre did not perform the operetta of Jenő Heltai and Albert Szirmai, but put another play in the program instead until the end of the case. $[\ldots]^{32}$

Unlike in the last two articles, on the columns of Pesti Napló ${ }^{33}$ we can read a remarkably detailed report. It is a valuable source material in several aspects: it shares important partial

\footnotetext{
${ }^{30}$ Tilos az Enyém az elsö csók. . . cit., 10.

${ }^{31}$ Húsz év előtt száz előadás. .., cit., 15.

${ }^{32}$ Ibid., 15.

${ }^{33}$ A rendőrség betiltotta az Andrássy úti színház. ., cit., 11.
} 
information - repetitions were removed from the text -, it elaborated at length on the intervention of director Wertheimer, police advisors dr Páll and dr Sándor Dóra took part in the trial.

But besides achieving some beneficial results, the theatre management also had to provide a new program as soon as possible.

[...] After receiving the notification, Elemér Wertheimer, director of the Andrássy Street Theatre went to the headquarters, where he met police advisor Páll, who said that the operetta was offensive to public morality, and because of that the performance had to be banned. This ban is the result of the report of chief advisor Puskás, and since the order has been signed by vice-commissioner Andréka, the Andrássy Street Theatre has the right only to appeal against the ban, but only outside the property, so Friday night's performance of Enyém az első csók cannot be given, either.

[...] In response to pleas, chief advisor Dóra replied that he could not grant even the least postponement. However, he also revealed that he had read the manuscript of the play and did not find anything wrong with it, but the topic of the play and especially its tendency could not be presented to the public in view of the existing strict regulations about the protection of public morality.

Director Wertheimer also argued that some private theatres were performing plays by foreign playwrights with far more serious topics and tendencies all the time without any ban from the police. He therefore urged that the literary work of one of the most outstanding Hungarian writers, Jenö Heltai be seen in the same way as the plays of a foreigner playwright. Director Wertheimer received a negative reply again, and with this, Enyém az elsö csók was removed from the program of Andrássy Street Theatre, at least for a while. [...] $]^{34}$

\section{ASSOCIATION OF HUNGARIAN PLAYWRIGHTS - EMERGENCY MEETING, PETITION}

It is important to mention that at the time of the ban the internationally known and acknowledged writer was the Chair of the association of Hungarian playwrights - a society which also included writers, translators and composers. His first administration at the head of the Association ${ }^{35}$ lasted from 18 April 1917 to 6 March $1919 .{ }^{36}$ He was Chair for a second time from 12 March 1922 to 16 June $1930 .{ }^{37}$ The Association ${ }^{38}$ provided legal representation in many cases, and from time to time it intervened with decision-making or executive authorities. This case was no different. The Association discussed the ban at an emergency meeting and it formed and sent a petition to the Minister of Interior. Many of its members expressed their indignation over the case, which can also be seen in the articles.

\footnotetext{
${ }^{34}$ Ibid., 11.

${ }^{35}$ Magyar Színpadi Szerzők Egyesülete [Association of Hungarian Playwrights]. In Magyar Színházmüvészeti Lexikon., cit., $477-478$.

${ }^{36}$ Ibid., 478.

${ }^{37}$ Ibid., 478.

${ }^{38}$ First period: $1904-1919$; Second period: $1920-1949$.
} 
The emergency meeting was described in detail in the article published on 19 May 1928 in Magyar Hirlap. ${ }^{39}$ The discussion of the new order from the Ministry of Interior- an adjective which hints at the fact that a new order was being planned - and the focus on the case at hand caused problems for the Association in many ways, because the members had to agree on their reaction to the ban and the above-mentioned order. The Association unanimously urged the immediate withdrawal of the police measures- despite the numerous points of incomprehension and the unanswered questions.

The management board of the Association of Hungarian Playwrights held an emergency meeting chaired by Jenő Heltai concerning the case of the order about the protection of copyrights issued by the Ministry of Interior, and the unexpected decision of the police to ban Jenö Heltai's operetta Enyém az első csók with immediate effect with reference to the protection of public morality.

The management of the Association of Hungarian Playwrights dealt with the new order of the Minister of Interior first. They agreed that they would wait until the order is published before they took any further measures, because the order does not deal with the collection of royalties and Hungarian playwrights find it natural to leave it to their association.

After that, they discussed the ban of the operetta in the Andrássy Street Theatre. The Association found the police measures incomprehensible and it turned to the Minister of Interior with confidence, asking for an immediate reversal of the police measures.

On Thursday night, police advisor Puskás saw the performance of the operetta Enyém az elsö csók in the Andrássy Street Theatre. On Friday, the theatre suddenly got an order from the police which informed the management that the play was banned with immediate effect. The measure surprised the management to an uncommon extent because this operetta by Jenö Heltai ran to a hundred performances twenty years ago, and at that time they did not find anything wrong with it.

The plot of the play is about the old rights of the lords and the right to the first kiss. This tale is told in manner which is witty and pleasing, using the finest artistic devices in Heltai's cosy operettasatire, so that we really cannot find anything wrong with it. And yet, now it is banned with reference to morality considerations. $[\ldots]^{40}$

The first part of the article published in Pesti Napló ${ }^{41}$ featured in the previous section; in the following passage we can read about the somewhat impetuous, near-enough rough statements by the people connected to the Association of Hungarian Playwrights (in order: Jenö Rákosi ${ }^{42}$, Zsolt Harsányi, ${ }^{43}$ Menyhért Lengyel - vice chairman, ${ }^{44}$ Lajos Zilahy ${ }^{45}$ ), and by its commissioner

\footnotetext{
${ }^{39}$ A Színpadi Szerzők rendkívüli közgyülésen foglalkoztak a belügyminiszter új rendeletével és a Heltai-operett betiltásával [Playwrights Association Discusses New Ruling by Minister of Interior and Ban of Heltai Operetta at Emergency Meeting]. Magyar Hírlap. vol XXXVIII issue 113 (19 May 1928) 4.

${ }^{40}$ Ibid., 4.

${ }^{41}$ A rendőrség betiltotta az Andrássy úti Színház. .., cit., 11.

${ }^{42}$ Jenő Rákosi (1842-1929) writer, journalist, theatre director. Jenő Rákosi. Magyar Színházmüvészeti Lexikon., cit., 638.

${ }^{43}$ Zsolt Harsányi (1887-1943) writer, journalist, translator, theatre director. Zsolt Harsányi. Magyar Színházmüvészeti Lexikon., cit., 289.

${ }^{44}$ Menyhért Lengyel (1880-1974) see his biography for example Menyhért Lengyel. Magyar Színházmüvészeti Lexikon., cit., 456.

${ }^{45}$ Lajos Zilahy (1891-1974) more about his career see Lajos Zilahy. Magyar Színházmüvészeti Lexikon., cit., 638.
} 
(Miklós Bezzegh-Huszár). These lines tell a lot about contemporary censure in general and about the public morale of the age.

As a reaction to the ban, the Association of Hungarian Playwrights with Jenö Heltai as its chairman called for an emergency meeting on Friday, at which they made a decision after a passionate discussion that they would turn to the Minister of Interior with an urgent petition and ask him on Saturday to take measures in this ominous case, which - as the Association of Hungarian Playwright says with all trust - can only be solved through the Minister of Interior.

The petition of the Association of Hungarian Playwrights, which was signed by Kálmán Csathó in lieu of Jenö Heltai, will be handed to the Minister of Interior by the Association's lawyer, dr Menyhért Palágyi ${ }^{46}$

About the case of the ban, the journalist of the Pesti Napló received the following statement:

Commissioner Miklós Bezzegh-Huszár: - I do not know about any ban against the play, nor do I know which police medium banned it. I have to add that nobody has from the theatre has turned to me with a complaint about such a ban, although the management would have had the right to appeal and come to me after the ban from police representative. ${ }^{47}$

Jenö Rákosi: - The faith of our actors and our entire theatre is now in the hands not of God, but of the police. It is sad that so little seems to have been left of the former's omnipotence.

Zsolt Harsányi: - I was not really surprised by the case of the Heltai play. You start to get used to it. Before a charity event where I spoke for free, the police officer insisted that I show him, in advance, the text of the speech I am about to deliver, because it may contain communist elements. Or, the other day, I got informed that in a countryside community, local morality forums prevented a performance of the famous play A Noszty fiú... [The Nosztys' boy] because in the last scene there is a woman who is expecting a baby, and that is considered obscene. So now I am beginning to think that I am forced to consider even my existence in the world obscene, because, to tell the truth, I was not brought here by a stork. What's more, my case is badly aggravated by the fact that even my son was not brought to us by a stork. Every literary work, including even the most shallow ones, has two forums: the aesthetic forum, i.e. the critics, and the judicial forum - the court. To order a third judging and evaluating forum over the literature of a country besides these two is a derogatory and savage act.

- Those doubtlessly gracious and excellent man, who have a word in this issue should see that this whole case is a gruesome piece of nonsense. On this same basis, the police officer could just as well visit the lecture of a professor of obstetrics at the medical university, because he may tell an obscene joke during his lecture, or he should witness a meeting of the Hungarian Academy of Sciences where there is a sociological debate and one of the academicians starts singing a communist tune. Naturally none of these can happen. But for me, it can happen. I resent that.

\footnotetext{
${ }^{46}$ It is probably a typo. Róbert Palágyi any Menyhért Palágyi can be seen in turns. Róbert Palágyi is the lawyer of the Association of Hungarian Playwrights indeed, proved by sources - see the reference above.

${ }^{47}$ This statement from the commissioner shows that the question of the banned play was finally decided on a much higher level.
} 


\begin{abstract}
Menyhért Lengyel: - It is incredibly unbelievable to stigmatize Jenő Heltai as immoral. He rose above his peers with the brilliant work of his whole life, and his name means true and great value not only in Hungary but abroad, as well. And the fact that this stigma was put on Heltai's little masterpiece by a police officer goes beyond all limits. Is it possible? Where does it go? That is unprecedented. We are amazed by this disgraceful decision, and our last hope is that this police measure that ridicules everything would be undone by a stroke of a pen from the highest forum.
\end{abstract}

Lajos Zilahy: - I find this decision absolutely absurd. This state has to be terminated immediately. $[\ldots]^{48}$

In the article published in $E s t^{49}$ on 20 May in addition to the details of the appeal from the Association, new information appeared about the ways in which Kálmán Csathó, ${ }^{50}$ Róbert Palágyi, ${ }^{51}$ and Sándor Sztranyavszky ${ }^{52}$ were involved in the case:

[...] By the way, the Andrássy Street Theatre appealed against the order. Besides that, the Association of Hungarian Playwrights turned to the Minister of Interior with a petition in which it asks him to take action against the order. The petition was signed by Kálmán Csathó in the name of the Association of Hungarian Playwrights and it was handed to state secretary Sztranyavszky by dr Róbert Palágyi, the lawyer of the Association. $[\ldots]^{53}$

\title{
"THE FORMALITIES OF THE MORALITY INVESTIGATION WERE INCREDIBLY IMPOSING AND SHOCKINGLY EXCITING." ${ }^{54}$ - LITERARY COURT - REVIEWS
}

On 20 May, the press in Pest reported that there was hope, the ministry of interior may yet permit the performance. To elaborate on this stage of the process, I reviewed articles from

${ }^{48}$ A rendőrség betiltotta az Andrássy úti Színház. .., cit., 11.

${ }^{49}$ A színpadi szerzők kérvénye a belügyminiszter a Heltai-Szirmai-operett betiltása miatt [Petition by Playwrights to the Minister of Interior Against the Ban of the Heltai-Szirmai Operetta]. Az Est. vol XIX issue 114 (20 May 1928) 4.; The beginning of the article focuses on general incomprehension. A színpadi szerzők kérvénye a belügyminiszter. .., cit., 4 .

${ }^{50}$ Kálmán Csathó (1881-1964) writer, director. Kálmán Csathó In Magyar Színházmüvészeti Lexikon., cit., $133-134$.

${ }^{51}$ Lawyer Róbert Palágyi: “[...] In the literature, he deals with issues related to copyrights, publishing rights and unfair competition. Lawyer of the Association of Hungarian Playwrights, National Association of Hungarian Motion Picture Producers and chief secretary of the Hungarian group of International Literary and Art Association.” In Magyar Színházmüvészeti Lexikon., vol III., cit., 430.

${ }^{52}$ Sándor Sztranyavszky. In Magyar Életrajzi Lexikon 1000-1990. Chief ed. Ágnes Kenyeres https://mek.oszk.hu/00300/ 00355/html/ABC14240/15314.htm.

${ }^{53}$ A színpadi szerzők kérvénye. .., op. cit., 4.

${ }^{54}$ Erkölcsbírák a nézőtéren. Két órán át vizsgáztatták az Enyém az első csókot, de nem határoztak [Morality Judges in the Audience. Enyém az első csók Examined for Two Hours but no Decision Made]. Újság. vol IV issue 115 (22 May 1928) 11. 
Budapesti Hírlap, ${ }^{55}$ Magyar Hírlap, ${ }^{56}$ Magyarország, ${ }^{57}$ Magyarság, ${ }^{58}$ and 8 Órai Újság, ${ }^{59}$ and as primer source I used writings from the first two newspapers and the article published in 8 Orai Újság.

Collegiate councillor dr Kálmán Tomcsányi was also involved in the case, minister of interior Scitovszky trusted him with the investigation, his intercession and personality got a positive evaluation in the press.

Against the ban of the operetta titled Enyém az első csók by Heltai and Szirmai, the Association of Hungarian Playwrights turned to the Minister of Interior. Following the proposal of Dr Kálmán Tomcsányi, Minister of Interior Béla Scitovszky immediately ordered the collegiate councillor himself to go and see a performance of the play incriminated by the police in the Andrássy Street Theatre, and he made the decision dependent on his opinion. This quick and emphatic decision was welcomed by both the Association of Hungarian Playwrights and the management of the Andrássy Street Theatre because they knew Kálmán Tomcsányi's impartial and wise way of thinking, which undoubtedly could only have a positive effect on the fate of the play, and so everyone was reassured even in advance. ${ }^{60}$

The writing published in Magyar Hirlap shows that the case points beyond itself - indeed, it was discussed not only in literary but also in political circles. The Ministry of Interior set the date of the performance's examination for Monday. They also gave a report about the planned interpellation of writer and member of parliament József Pakots ${ }^{61}$ :

[...] The management of the Andrássy Street Theatre has appealed against the police decision and this appeal was forwarded to the Minister of Interior. Minister Béla Scitovszky decided that on Monday afternoon a committee from the Ministry of Interior was to appear in the auditorium of the Andrássy Street Theatre, the actors would perform the play for the committee and the Minister of Interior was to make a decision based on the report of the committee.

Of course, the banning decision of the police attracted attention, and it was discussed not only in literary but also in political circles, since Jenő Heltai and Albert Szirmai were two great and internationally acknowledged personalities in Hungarian literature and composition, so it would have been strange to label them as immoral. In literary circles, there had already been protests against the police ruling, and today MP József Pakots gave an interpellation concerning the case of Enyém az elsö csók. The interpellation will be read at the Wednesday meeting of the House of Representatives even if the Minister of Interior does eventually change the police ruling. József

${ }^{55} \mathrm{Az}$ Enyém az első csók betiltása [Ban on Enyém az első csók]). Budapesti Hírlap. vol XLVIII issue 114 (20 May 1928$) 18$.

${ }^{56}$ Pakots József interpellál a Heltai-Szirmai-operett betiltása ügyében [József Pakots Interpellates in the Case of The Heltai-Szirmai Operetta's Ban]. Magyar Hírlap. vol XXXVIII issue 114 (20 May 1928) 4.

${ }^{57}$ A belügyminiszter elrendelte az Enyém az elsö csók revízióját. [Minister of Interior Orders Revision of Enyém az első csók] Magyarország. vol XXXV issue 114 (20 May 1928) 16.

${ }^{58}$ Revideálják a Heltai-operett betiltásának ügyét [Ban on Heltai Operetta Revised]. Magyarság. vol IX issue 114 (20 May 1928) 22.

${ }^{59}$ A betiltott Enyém az elsó csók. Remény van arra, hogy a belügyminiszter engedélyezni fogja a darab további előadásait [Enyém az első csók Banned. There is Hope, that Minister of Interior May Allow Further Performances]. 8 Órai Újság. vol XIV issue 114 (20 May 1928) 9.

${ }^{60}$ (Az Enyém az elsö csók betiltása), cit., 18.

${ }^{61}$ József Pakots. Magyar Életrajzi Lexikon 1000-1990. Chief ed. Ágnes Kenyeres. 
Pakots told our colleagues that since we are talking about a considerable establishment, it should not be allowed for the police to act as the highest literary forum and to stigmatize writers and their jobs as immoral with a single stroke of a pen. It is especially hurtful when it is about such great men as those affected in the present case. $[\ldots]^{62}$

8 Órai Újság succeeded in eliciting an interview from the play's other director, Lóránd Barabás, ${ }^{63}$ who said the following:

[...] We asked Lóránd Barabás, dramaturge director of Andrássy Street Theatre about the case, who said the following to our colleague: - Until the midday hours there has been no decision about the withdrawal of the play, but there is hope - the Ministry of Interior may change its position in the case and it may allow the performance of Enyém az elsö csók again. When we can hope to schedule a new performance of the play of course depends on the time we get notified about the decision. Perhaps we can already perform the play today, or we may need to wait a day or two before we can stage it once more. [... $]^{64}$

We can safely say that the press gave the most detailed report on the performance given for the benefit of the committee, since reporters could follow the events on Monday afternoon from outside the theatre, even if not from the inside; furthermore, they could also managed to interview some of the people concerned. In this case, I selected articles from Magyar Hirlap, ${ }^{65}$ Pesti Napló ${ }^{66}$ and Újság. ${ }^{67}$

The company first met in the director's office in the Andrássy Street Theatre - of the creators of the play only Albert Szirmai appeared in person, while author Jenö Heltai was represented by Menyhért Lengyel. The committee consisted of vice-commissioner Károly Andréka, advisor to the Ministry of Culture Ödön Mariay, Zoltán Farkas, Kálmán Tomcsányi and chief advisor György Puskás - who was to write the report about the play -sat in the front row. Only a few people could get into the hall or hide behind the curtains, firstly because such censorship performances were private, and secondly because the detectives who were sent to the theatre took care to keep away journalists and uninvited visitors.

First, let us see the report given by Magyar Hírlap. The newspaper interviewed József Pakots, who could only repeat his earlier, angry words:

[...] A few minutes after four o'clock the members of the committee arrived. Vice-commissioner

Károly Andréka, advisor to the Ministry of Interior Kálmán Tomcsányi, police advisor György

\footnotetext{
${ }^{62}$ Pakots József interpellál a Heltai-Szirmai-operett. .., cit., 4.

${ }^{63}$ In some press sources of this study, names "Lóránd" and "Lóránt" were corrected, because in various encyclopaedias the form "Lóránd” was used, so I followed these.; Lóránd Barabás (1884-1941) writer, dramaturge, theatre director. In Magyar Színházmüvészeti Lexikon., cit., 59.

${ }^{64}$ A betiltott Enyém az elsö csók. .., cit., 9.

${ }^{65}$ Lejátszották belügyminisztériumi bizottság előtt a betiltott Heltai-operettet. A bizottság döntését kedden hirdetik ki [Banned Heltai Operetta Performed for the Committee of Ministry of Interior. Decision To Be Announced on Tuesday]. Magyar Hirlap. vol XXXVIII issue 115 (22 May 1928) 8.

${ }^{66}$ Irodalmi törvényszék az Andrássy úti Színházban. Döntés: kedden délelött. [Literary Court in Andrássy Street Theatre. Decision On Tuesday]. Pesti Napló. vol LXXIX issue 115 (22 May 1928) 12-13.

${ }^{67}$ Erkölcsbírák a nézőtéren. Két órán át vizsgáztatták az Enyém az első csókot, de nem határoztak [Morality Judges in the Audience. Enyém az első csók Examined for Two Hours but no Ruling Made]. Újság. vol IV issue 115 (22 May 1928) 11.
} 
Puskás, advisor to the Ministry of Culture Ödön Mariay, theatre critic of Budapesti Hírlap Zoltán Farkas, former managing editor of recently abolished periodical Szózat and is now theatre critic for Új Nemzedék.

The censorship performance of the Enyém az elsö csók is about to start. József Pakots is on the stage behind the curtains. Members of the committee are seated in the front rows.

A gong, the curtain goes up, Rátkai is seen on the stage in the spectacular costume of a medieval lord. He is sitting on the throne with Böske Tóth next to him, and on the right sings the joyful choir of the little operetta: Today is different, / From other days, / Today it ends, / Today it ends / The Middle Ages end.

Then the story of the play begins. Rátkai plays with noticeable indisposition. No wonder: the audience does not react to his jokes. ${ }^{68}$

The performance ends at a quarter to five, the committee members go to art director Lóránd Barabás's office to discuss whether or not they should authorize the performances of the play.

[...] - I have the most honest impression - said József Pakots -, that Jenő Heltai's play is an uncommonly fine and great piece of theatre. The tune of the little operetta, its satire and its humor are not hurtful or frivolous, but truly refreshing. This performance can only justify the success of the play twenty years ago.

Then the question arises, why the decision about the revival of a play so successful twenty years previously is not made by an impartial artistic committee.

Director Elemér Wertheimer, director of this little theatre, says that he will have to close down the theatre if Enyém az elsö csók is not allowed to stage, because their current season was founded on this operetta.

After a forty-five minute discussion the committee members left the theatre and director Wertheimer asked ministry advisor Tomcsányi about the committee's decision. But Tomcsányi only said that he would report to Minister of Interior Scitovszky on Tuesday morning, who was to bring the final ruling in the case.

Regardless of the committee's decision, József Pakots was to speak out about the case of the ban in Parliament so as to prevent further instances where a theatre performance is banned based on a report from a police officer, depriving hundreds of people of their livelihood.

'This case is special', said Pakots, 'because the author of the banned play is Jenö Heltai. I will ask the Ministry of Interior to ask the Hungarian embassy in Paris to give information about Jenő Heltai. In the French Foreign Office they know him well. Here, in Hungary, they obviously don't. . ${ }^{69}$

The report in Pesti Naplo projected the atmosphere of the statements made by József Pakots and Menyhért Lengyel over the entire text. It also described a discussion between director Wertheimer and Tomcsányi. They referred to the case as a medieval trial, using of course the rhetorical opportunities given by the medieval story (for example: "Jeno" Heltai made a mistake when he wrote that "The Middle Ages have ended. ${ }^{70}$ ). For the eventuality of a

\footnotetext{
${ }^{68}$ In another, later article we can read that the audience - especially Tomcsányi - smiled or laughed many times.

${ }^{69}$ Lejátszották belügyminisztériumi bizottság. . ., cit., 8 .

${ }^{70}$ Irodalmi törvényszék. . ., cit., 12.
} 
final ban, Heltai envisages renouncing his position as a chairman of the Association of Hungarian Playwrights.

[...] The committee, which includes vice-commissioner Andréka as member, consists of nine people, three of them right-wing literary critics. [...]

When the meeting of the committee started, MP József Pakots, who saw the performance from behind the curtains, appeared in the audience. József Pakots said the following:

- Enyém az elsö csók is a fine, cozy, high-end operetta. It is ridiculous even to think about banning it. The noble-sounding name of Heltai and this high-end, literary libretto, and this great music from Szirmai: these can only give us reason to celebrate Heltai and Szirmai. Banning them! To hurt them by charging them with immorality? This is a sin indeed. The little operetta starts with a song, and its last line says that the Middle Ages had ended. When I look at the events around this operetta, when I see this terribly somber literary court with members who have had nothing to do with literature before, and when I remember that this gratuitous decision of the police can be sanctioned by the court, I have to say that Heltai was in fact mistaken when he wrote that "The Middle Ages had ended"

- About this whole case, I will speak out in the House on Tuesday. The entire predicament is thoroughly incredible and hideous. A police officer judging about a Heltai operetta. A single word from a police officer is enough to stigmatize this little masterpiece by Heltai as immoral and obscene, and to ban it once and for all. It is also incredible that it should be not a representative of the Ministry of Culture, but someone from the Ministry of Interior - who may be a great administration expert, but certainly not a judge in a literary case - who passes judgment at second instance as to what kind of playwright Heltai is and whether his brilliant play is unworthy of being performed in front of the audience in Pest.

Now Menyhért Lengyel takes over. He angrily proclaims,

'Hungarian writers, let us put down our pens! Everything is in vain here. Does it depend on the mood of police officers if Heltai can write, and whether, when he writes something, it can be performed in a theatre? With this method, it is not only the Hungarian writers who can be made miserable, but a theatre can also be destroyed in twenty-four hours. And this is happening now, when Hungarian acting is in the greatest crisis, and theatres are in the hands of God more than ever. I do not know what could be done against all of this. We are standing here feeling helpless.

Meanwhile, in the director's room, the meeting goes on. Nobody outside can know anything for certain. A detective is standing by the door of the meeting room. But after a forty-five minute meeting, the door of the meeting room opens, an advisor representative of the ministry comes out and calls in vice-commissioner Andréka and police advisor Puskás from the street. The meeting continues. Finally, at half past five the committee members appear at the door. Director Elemér Wertheimer rushes to Kálmán Tomcsányi, who says the following: - The committee did not bring a final ruling, it will be done tomorrow. [...]

That is all. Is that not exactly like a medieval story?.. ${ }^{71}$

From the paper Újság I found it important to highlight the following details, and it is also worth paying attention to the highly ironic style of the report:

${ }^{71}$ Irodalmi törvényszék. . ., cit., 12-13. 
[...] The gentlemen entered the theatre hall and took their seats scattered in the rows. They clearly wished to examine the obscene play from every angle. [...]

The head of the committee was ministry advisor Kálmán Tomcsányi, whose name is mostly known to the public in connection with bans. [...]

The formalities of the morality investigation are highly impressive and shockingly exciting.

Two detectives were standing at each door of the hall, dressed in black. Nobody could go in or out.

[...] On the stage, among others, we could see MP József Pakots, who definitely did not want anyone to know that he had seen Enyém az elsó csók - an instance as disgraceful for Members of Parliament as it is for young girls.

After the performance the committee went into the director's office. When the curtains finally descended upon this blight of the dramatic arts, the detectives left. In the hallway, we surprised representative Imre Györki, who had probably been trying to lurk around the keyhole, but felt afraid of the detectives.

The committee retired to the office. The young man looked out of the door several times before he went to completed the numbers of the committee. He invited a few gentlemen of the police inside, attending merely as private citizens. The supplementary committee was locked up again and continued the meeting.

Actors and other employees of the theatre, for whom the ban was an existential question, walked nervously up and down the corridors. Besides journalists this included other intrigued individuals such as Menyhért Lengyel. ${ }^{72}$

Finally the door opened. Ministry advisor Tomcsányi appeared in coat and hat. He words he spoke to theatre director Elemér Wertheimer were the following, 'We have not made a decision in the case. We shall report to his excellency the Minister of Interior. Please come and see me later.' Then they left. $[\ldots]^{73}$

On 23 May, a report was published in Esti kurír ${ }^{74}$ from which the reader of the time could learn about the events accurately to the hour and even to the minute, and it also shed light on the reaction of the judging audience:

[...] 4.15 p.m.: The doors of the theatre hall open. The detectives check everyone. They literally stop people for identification without saying a word. No one else is allowed to enter except the members of the committee. Albert Szirmai, the composer of the operetta wants to go in. They allow him, but finally he is forced to sneak in the hall in the dark. Menyhért Lengyel also goes in as the representative of Jenö Heltai who is in Berlin at the time.

The committee in charge of protecting public morality seat themselves in the first two rows. [...]

'What you sang is right', says Rátkai, referring to the libretto which proclaims that today the Middle Ages end.

\footnotetext{
${ }^{72}$ Menyhért Lengyel represented Heltai, he was not only a "curious person" on the event.

${ }^{73}$ Erkölcsbírák a nézőtéren. ., cit., 11.

${ }^{74}$ Módosításokkal engedélyezték a betiltott Heltai-operett előadását, de a belügyminiszter továbbra is helyesli a rendőrség eljárását [Performance of Banned Heltai Operetta is Allowed with Some Modifications, but Minister of Interior Still Thinks that Police Measures Were Right]. Esti Kurir. vol VI issue 116 (23 May 1928) 7.
} 
Everyone is looking at Tomcsányi. Tomcsányi laughs, Andréka laughs, the two literary potentates smile.

4.12 p.m.: The document about the termination of the Middle Ages is handed to Márton Rátkai, who, as befits an illiterate knight, looks at it upside down.

'It is upside down', the courier warns him.

'No problem', says Rátkai, 'a true knight can read upside down'.

Tomcsányi nods and laughs.

\section{Tomcsányi laughs, Rátkai worries because the Middle Ages are to end.}

4.22 p.m.: So, at 12 o'clock the Middle Ages are to end. Naturally, Márton Rátkai is eager to know what time it is.

He takes his hourglass from the pocket of his vest, takes a look at it and says, 'It is only ten o'clock.'

Tomcsányi laughs.

4.40 p.m.: The village girls arrive to give the first kiss before their marriage to the squire, true to the custom. Song: Blessing and peace / Blessing and peace / We are the brides / From the village.

Tomcsányi laughs.

4.45 p.m.: The old lord is scared, as the Middle Ages are to end within two hours and he still has three hundred girls to kiss on the lips.

'I am three hundred behind', says Rátkai and his face registers scare.

Tomcsányi laughs.

4.45 p.m.: The grooms arrice. Song: Blessing and peace / Blessing and peace / We are the sad grooms / From the village.

Tomcsányi laughs.

The landlord seems to be enjoying the goings-on, but the attraction is over.

4.46 p.m.: Irén Biller dances onto the stage. Now comes her duet with Rátkai. [...]

Tomcsányi laughs. Andréka laughs and the literary potentates laugh.

4.48 p.m.: The old lord now almost likes the idea of the first kiss. But the clock strikes twelve, which means that the Middle Ages have come to an end, the medieval customs must die.

'The Middle Ages are over,' he says. 'I no longer have the right to anything.'

4.50 p.m.: The play ends. Advisor to the Ministry of Interior Kálmán Tomcsányi laughed eight times in thirty-five minutes at Jenő Heltai's obscene operetta. The rest of the story is known: the police officers stood by the door and Tomcsányi retired into the director's office with his literary advisors where they had a long discussion about what to do about this frightful play. [... $]^{75}$ 


\section{AN OUTLOOK: MORALITY PROTECTION TO THE BITTER END - 20 MAY 1928}

One of the benefits we may hope to gain from this case is if the Ministry of Interior were to reconsider the application of the law about the morality protection to theatre (or other artistic) performances or use a totally different method to supervise them if necessary. The playwrights also hoped for such an outcome, but police have also taken action with regard to the operetta Yes. The two cases are connected in articles reporting on the fate of Yes. We can assume that in this case the common outrage about the ban of the Heltai-Szirmai operetta has caused those involved to think the matter over. On 20 May Pesti Napló published the following article concerning the significance of the case of Enyém az elsó csók in connection with Yes, and playwrights in general, A Yes szövegkönyvét vasárnap délelött felülvizsgálja a rendörség. Erkölcsvédelem a végkimerülésig [Libretto of Yes to be Reviewed by Police on Sunday Morning. Morality Protection to the Bitter End $]^{76}$ :

One day has passed since the performance of Heltai and Szirmai's operetta in the Andrássy Street Theatre was banned. This gratuitous act was followed by loud protest on behalf of the entire community of writers and actors. In the columns of Pesti Napló, the greatest Hungarian playwrights expressed their views on the case and emphasized that such a case of police censure will have the most serious consequences unless it is revoked without delay, and that all it can avail is to cause serious and irreparable damage to our theatres already struggling with huge problems, and to drive Hungarian writers into utter apathy. [...]

For a while after the measures of the Ministry of Interior things seemed to calm down a little and, it was believed that, at least for the present, police would stop pestering theatres in Pest. That was not the case. Yvain's new operetta, Yes, premiered in the Hungarian Theatre on Friday evening. The press wrote about the play in positive tones and even the strictest critic could find no fault with the libretto of this delightful and successful little operetta. It seems that that the police's opinion is again different from that of the audiences of Budapest and the critical appraisal given by the people that city. This is proved by the fact that the management of the Hungarian Theatre received summons from the headquarters in which they request the head of the theatre to report at the Permissions Department on Sunday morning and present the entire libretto of Yes.

Naturally, for the present it is unknown what might be the final goal of the police with this request, but has undeniably brought uncertainty upon stage plays which are of acknowledged value on every stage around the world, and whose destiny is now to be discussed or judged at the "department of permissions « after performances have been discontinued. ${ }^{77}$

\footnotetext{
${ }^{76}$ A Yes szövegkönyvét vasárnap délelőtt felülvizsgálja a rendőrség. Erkölcsvédelem a végkimerülésig. Pesti Napló. vol LXXIX issue 114 (20 May 1928) 19.

${ }^{77}$ A Yes szövegkönyvét vasárnap. .., cit., 18.
} 


\section{"SO IT WAS ABOUT OF TWO CLAUSES"78 - 22 MAY 1928}

The permission which finally authorized the theatre to include the operetta in its season's program was received by the management on 22 May. The press, as was to be expected, reported the fact, and a few days later a "sample text advertisement" newspaper:

Now that the Heltai-Szirmai operetta Enyém az elsó csók - which was first banned and then repermitted - is once again being performed as part of the series Kacagó Esték [Laughing Evenings], audiences are giving the play a standing ovation night after night. This flawless little play is a huge success due to its brilliant wit, beautiful music and the acting of Márton Rátkai, Böske Tóth, and Pál Fekete. In fact the entire program is a huge success, with ticket prices ranging up to 6 Pengö. ${ }^{80}$

This case is especially absurd because the "morality judges", in other words the the committee from the Ministry of Interior, withdrew the ban, partly yielding to pressure. But the way in which this "withdrawal" took place is almost comical in itself, since the Ministry of Interior deleted the total of two sub-clauses from the script. There was no censorship here, asserted the Minister of Interior when asked about the events by 8 Órai Újság. Scitovszky talked about the monitoring of the plays in general, and he said that such "inconveniences" could be easily avoided if theatre companies submitted their scripts in advance.

[...] - I altered the ruling of the headquarters and authorized the performance of the play with the appropriate modifications.

The police had made the right decision when they vetoed the play because of its libretto and its manner of performance. When the case reached me I examined the relevant points and altered the police ruling after considering several aspects. I ordered the theatre management to introduce moderation to those parts of the play which had justified the police ruling.

Usually, I am no friend of censorship, either, and do not wish to exercise it, because I find it personally difficult. The professionals involved need to know their won boundaries and whenever they go beyond these, they render it necessary for the police to intervene. I do not only consider moral aspects, but also take into account the fact that for a theatre which performs a play, the measures I might introduce in cases like this can easily cause difficulties. I strive not to cause any

\footnotetext{
${ }^{78}$ Két mellékmondatot kellett kihúzni Heltai Jenő librettójából. Engedélyezték a további előadásokat [Two Sub-clauses had to be Deleted from Jenő Heltai's Libretto. Further Performances Permitted]. Pesti Napló. vol LXXIX issue 116 (23 May 1928) 11.

${ }^{79}$ See the text published in 8 Órai Újság with only a few modifications, among others: Heltai-Szirmai Enyém az első csók operettének tüntető sikere az Andrássy úti Színházban [Demonstrative Success of Heltai-Szirmai Operetta Enyém az első csók in Andrássy Street Theatre]. Pesti Napló. vol LXXIX issue 119 (26 May 1928) 13.; Heltai-Szirmai Enyém az első csók operettének tüntető sikere az Andrássy úti Színházban. 8 Órai Újság. vol XIV issue 120 (27 May 1928) 10.; Az újra engedélyezett Enyém az elsö csók [Enyém az elsó csók Re-Authorized]. Esti Kurir. vol VI issue 125 (3 June 1928) 10.; Az újra engedélyezett Enyém az első csók. . Pesti Napló. vol LXXIX issue 124 (2 June 1928) 15.; Further articles which give a shorter report about the re-authorized performance are, e.g.: Az újra engedélyezett Enyém az első csók... Magyarság. vol XXXV issue 120 (27 May 1928) 12.

${ }^{80} \mathrm{Az}$ újra engedélyezett Enyém az elsö csók. Biller Irén - Rátkaival az Andrássy úti Színházban - A legdrágább jegy 6 pengő [Enyém az első csók Re-Authorized. Irén Biller with Rátkai in Andrássy Street Theatre -Most Expensive Tickets at 6 Pengő]. 8 Órai Újság, vol XIV issue 121 (30 May 1928) 11.
} 
damage to anyone. However, moral requirements must naturally enjoy priority and obligation of the police authorities when they make measures which are necessary considering public morals.

- When I look at the showcases, I am happy to see that the issues that might have been experienced in the past in terms of public morality have disappeared. If there are any concerns about the play, these should be clarified before the performance.

When it comes to concerns like that, it is not a matter of censorship so much as a friendly opinion, and such points can be modified in order to avoid any unnecessary expenditure, as this aspect of things cannot be taken into consideration when it the protection of public morality is at stake. $[\ldots]^{81}$

The summary ${ }^{82}$ given by Pesti Napló on 23 May focused on the financial aspect which since we are talking about private theatre companies and businesses - was indeed a serious problem endangering the very survival of the theatres in question.

[...] Vice-commissioner Andréka told the director of Andrássy Street Theatre which were those sensitive parts that had to be deleted from the play. It soon turned out that they were talking about a mere two sub-clauses. These two sub-clauseswere immediately deleted from the libretto of the operetta.

So it had all been about two sub-clauses. The Andrássy Street Theatre was empty for four weeks because of two sub-clauses, Jenö Heltai, this great Hungarian writer known all around Europe was convicted of a crime against morals and decency committed by his enchanting little masterpiece because of two sub-clauses. Two sub-clausesneeded to be deleted from the script of the operetta after the mobilization of Hungarian writers, Hungarian public opinion, and the relevant department of the Ministry of Interior, so these two sub-clauses must be remembered now. $[\ldots]^{83}$

\section{CENSORSHIP IN THEATRES AS A COMMON PROBLEM - ACTION AGAINST POLICE ASSAULTS}

The case and the measures we have described were far from unique, even if the episode of the Heltai-Szirmai operetta received the most attention in the press. On 24 May 1928 Pesti Hirlap also published the interpellation of the writer and Member of Parliament József Pakots, in which he brought up a new argument against the application of the decree of morality protection on literary works:

[...] he criticized the measures of the police, namely that they censored certain plays and banned several of literary value. The decree on morality protection did not do much good for us abroad. The writer of the banned operetta, Jenö Heltai had only just reviewed the French Medal of Honor as a

\footnotetext{
${ }^{81}$ Scitovszky belügyminiszter engedélyezte a betiltott Heltai-darab előadását [Minister of Interior Scitovszky Permits Performance of Heltai Play]. 8 Órai Újság. vol XIV issue 116 (23 May 1928) 12.

${ }^{82}$ Két mellékmondatot kellett kihúzni Heltai Jenő librettójából. Engedélyezték a további előadásokat [Two Sub-Clauses Had to be Deleted from Jenő Heltai's Libretto. Further Performances Permitted]. Pesti Napló. vol LXXIX issue 116 (23 May 1928) 11.

${ }^{83}$ Két mellékmondatot kellett kihúzni. .., cit.,11.
} 
token of appreciation for his literary work. It is typical of police censorship that after deleting one or two harmless sentences - by the order of the minister of interior - they authorised the play once more. $^{84}$

Scitovszky confirmed the official position of the Ministry of Interior in his answer - as he did in his previous statements ${ }^{85}$ - which stated that the ban and the supervising of the play were indeed necessary.

[...] The police supervise performances with regard to their impact on public morality. It is the state's interest to prohibit the debauchery of morals. The performance in question, and some parts of the play itself, go beyond the boundaries of good taste and morals. It is possible to have fun, be entertained and mock things within the confines of good morality. In the future, theatres will have to present the script of each play in advance, that way the problem can be solved without causing financial difficulty, while revising performances with a view to their moral aspects. (The House acknowledged the answer.) $[\ldots]^{86}$

"We can say that the case would have had far more serious consequences than they had thought." ${ }^{87}$ - wrote the journalist of Magyarország in an article about the incident published on 24 May. As we know, even a few days' ban caused a huge drop in income for the Andrássy Street Theatre, but the playwrights urged a common action against censorship and police assaults in theatres.

Yesterday evening the banned operetta by Jenö Heltai and Albert Szirmai was re-included in the program of the Andrássy Street Theatre following minor alterations. [...] Now that the files of this inconvenient case are closed and the little operetta has again been performed to huge applause from the audience, we can safely say that the case could have had far more serious consequences then they had thought. The head of the Andrássy Street Theatre decided that if the Minister of Interior does not change the police ruling, the theatre was to close its doors without delay, one month before its regular summer break.

The director of another theatre was threatened with a fine if unless he delete incriminating parts in a play. This prestigious director from Budapest has been at the head of a noted Hungarian theatre for a quarter of a century. He told our colleague that he would not pay the fine, but would exercise his right to serve his sentence instead. This is the way in which he would wish to protest against police measures.

We have learnt that the Association of Theatre Directors, the Association of Playwrights and the Theatres Association were launching a joint law suit against the assaults of the censorship, after having declared their protest at their subsequent meeting. ${ }^{88}$

\footnotetext{
${ }^{84}$ Interpellációk [Interpellations], Pesti Hírlap. vol L issue 117 (24 May 1928) 8.

${ }^{85}$ See for example the previously mentioned article Minister of Interior Scitovszky Permits Performance of Heltai Play. 8 Órai Újság. vol XIV issue 116 (23 May 1928) 12.

${ }^{86}$ Ibid., 8.

${ }^{87}$ A rendőrség betiltó rendelkezése miatt be akarta zárni kapuit az Andrássy úti Színház. Együttes akció készül az illetéktelen cenzúra ellen [Adrássy Street Theatre Wanting to Close Doors Due to Police Ban. Common Action planned Against Unwarrantable Censorship]. Magyarország. vol XXXV issue 117 (24 May 1928) 9.

${ }^{88}$ Ibid., 9.
} 
After this, the decree on morality protection and the issue of censoring theatres remained on the agenda, and playwrights and artists - as well as other associations, groups and communities, etc. - urged the revision of the decree, as we could see in the above-mentioned sources. They also found it absurd that the police subordinated to the Ministry of Interior should take measures concerning issues that would normally belong to the Ministry of Culture. This is proved by the fact that the first Congress of Fine Arts and Literature - which gave occasion for a meeting of a range of relevant departments - also made it one of its goals to discuss and later to resolve this problem.

The Congress of Fine Arts and Literature will demand the termination of censorship in theatres and the abolition of related police fees and taxes on entertainment. The first Congress of Fine Arts and Literature will be opened on 4 June in the Research Hall of the Houses of Parliament.

Participants have agreed to submit numerous proposals to Congress, including the demand for the termination of theatre censorship and of the application of public morality regulations to theatres. The explanatory section of the proposal quotes a range of related laws all the way from the 1848 decree abolishing censorship, demonstrating that the decree on the protection of public morality lacks legal foundations. $[\ldots]^{89}$

\section{SUMMARY}

By selecting from contemporary press sources and putting them into context, the goal of this study has been to present the absurd incidents of banned theatre performances in Hungary and to provide an insight into the application of contemporary decrees for the protection of public morality. We have also explored the operation of the Andrássy Street Theatre - the performance of the play on the opening night, the danger of of breakdown etc. - and attempted to enhance our knowledge, in a chronological sequence, about the way in which the Association of Hungarian Playwrights was connected to the case. As we could see, this incident was not unique, several plays were banned temporarily or permanently by the Ministry of Interior, and this was one of the reasons why Hungarian playwrights urged to organize an association for protecting their interests, and urged to reform the decrees in question.

As a final thought I would like to highlight a few sentences from an article published in Pesti Hirlap on 23 May:

[...] We must all remember what happened to a theatre, a theatre's audience and, above all, to the very best writers of the country within four days in May 1928 in Budapest, just because after a delay of four days, the police needed to delete two sub-clauses from a one hour play simply in order to put a patch on the "literary mistake" of a police advisor. ${ }^{90}$

\footnotetext{
89"Congress of Fine Arts and Literature to Demand Termination of Censorship in Theatres and Decrease of Police Fees and Entertainment Taxes.” Az Est vol XIX issue 120 (27 May 1928) 12.; Further summaries about the events include, for example, Az első magyar irodalmi és müvészeti kongresszus [First Congress of Fine Arts and Literature]. Magyar Müvészet vol IV issue 3 (1928) 273-274.

${ }^{90}$ Két mellékmondatot kellett kihúzni. .., cit., 11.
} 


\section{REFERENCES}

Alpár, Á. (Ed.) (1974). A fóvárosi kisszínházak müsora. A Tháliától a felszabadulásig 1904-1944 (Adattár). [The program of the small theatres in the capital. From Thalia to the liberation 1904-1944] Ed. Ágnes Alpár. Institute of Hungarian Theatre, Budapest.

Bános, T. (2011). A pesti kabaré [Cabaret in Pest] In: Gajdó, T. (Ed.), Magyar Színháztörténet 1873-1920 [Hungarian theatre history 1873-1920]. Magyar Könyvklub - OSZMI, Budapest, pp. 656-676.

Batta, A. (1998). Magyar operett a Monarchia széthullása után. In: Kollega-Tarsoly, I. (Ed.), Magyarország a XX. században III. kötet. Kultúra, müvészet, sport és szórakozás. Babits Publisher, Szekszárd, pp. 515517.

Győrei, Z. (2005). Heltai Jenö drámai életmüve [The dramatic work of Jenö Heltai]. L 'Harmattan, Budapest. Magyar Életrajzi Lexikon 2. [Hungarian encyclopaedia of Biographies vol. 2]. (1982). Akadémiai Publisher, Budapest.

Molnár Gál, P. (2006). Márton Rátkai. Mozgó Világ [Moving World], XXXII(9): 121-125.

Móricz, Z. (1929). Márton Rátkai. Nyugat, XXII(1).

Schöpflin, A. (Ed.) (1929). Magyar Színházmüvészeti Lexikon I. [Encyclopaedia of Hungarian Theatre Arts, volume 1]. National Actors' Association and Pension Institute, Budapest.

Schöpflin, A. (Ed.) (1930). Magyar Szinházmüvészeti Lexikon III. [Encyclopaedia of Hungarian Theatre Arts, volume III]. National Actors' Association and Pension Institute, Budapest.

Székely, G. (Ed.) (1994). Magyar Színházmüvészeti Lexikon. Akadémiai Publisher, Budapest.

\section{PRIMARY AND SECONDARY SOURCES (SORTED BY THE ORIGINAL PUBLICATION DATE)}

The Opening of the Modern Theatre. Pesti Hírlap. vol XXIX issue 240. (9 October 1907) 7. The Opening of a Modern Theatre... Pesti Napló. vol LVIII issue 240. (9 October 1907) 16. A Modern Színház megnyitása. Az Újsag vol V issue 242. (12 October 1907) 12.

Magyarországi Rendeletek Tára [Archive of Hungarian Decrees], 1923, vol 52. Hungarian Ministry of Interior 1924, 185-187.

How did Enyém az elsó csók get from Jenő Heltai to Jenő Heltai. Esti Kurir. vol VI issue 112 (17 May 1928) 11. Premiere in Andrássy Street Theatre. 8 Órai Újság. vol XIV issue 112 (17 May 1928) 9.

Tilos az Enyém az elsö csók elöadása [Performance of Enyém az elsö csók Banned]. Újság. vol IV issue 113 (19 May 1928) 11.

Húsz év előtt száz előadás, ma - betiltás. [A Hundred Performances Twenty Years Ago, Today - a Ban] Pesti Hírlap. vol L issue 113 (19 May 1928) 10.

A rendőrség betiltotta az Andrássy úti Színház Heltai-Szirmai operettjét. Bezzegh-Huszágh fókapitány nyilatkozik - Tiltakoznak az írók [Police Bans Heltai-Szirmai Operetta in Andrássy Street Theatre. Commissioner Bezzegh-Huszágh Makes Statement - Playwrights Protest]. Pesti Napló. vol LXXIX issue 113 (19 May 1928) 11.

A Színpadi Szerzők rendkívüli közgyülésen foglalkoztak a belügyminiszter új rendeletével és a Heltaioperett betiltásával [Playwrights Association discusses new ruling by Minister of Interior and Ban of Heltai Operetta at Emergency Meeting]. Magyar Hírlap. vol XXXVIII issue 113 (19 May 1928) 4. 
A színpadi szerzők kérvénye a belügyminiszter a Heltai-Szirmai-operett betiltása miatt [Petition of Playwrights to the Minister of Interior Against the Ban of Heltai-Szirmai Operetta]. Az Est. vol XIX issue 114 (20 May 1928) 4.

A Yes szövegkönyvét vasárnap délelőtt felülvizsgálja a rendőrség. Erkölcsvédelem a végkimerülésig. Pesti Napló. vol LXXIX issue 114 (20 May 1928) 19.

Erkölcsbírák a nézőtéren. Két órán át vizsgáztatták az Enyém az első csókot, de nem határoztak [Morality Judges in the Audience. Enyém az elsö csók Examined for Two Hours but no Decision Made]. Újság. vol IV issue 115 (22 May 1928) 11.

Az Enyém az első csók betiltása [Enyém az első csók Banned]). Budapesti Hírlap. vol XLVIII issue 114 (20 May 1928) 18.

Pakots József interpellál a Heltai-Szirmai-operett betiltása ügyében [József Pakots Speaks in Parliament in Case of Heltai-Szirmai Operetta Ban]. Magyar Hírlap. vol XXXVIII issue 114 (20 May 1928) 4.

A belügyminiszter elrendelte az Enyém az első csók revízióját. [Minister of Interior Orders Revision of Enyém az első csók] Magyarország. vol XXXV issue 114 (20 May 1928) 16.

Revideálják a Heltai-operett betiltásának ügyét [Ban on Heltai Operetta Revised]. Magyarság. vol IX issue 114 (20 May 1928) 22.

A betiltott Enyém az első csók. Remény van arra, hogy a belügyminiszter engedélyezni fogja a darab további előadásait [Still Hope for Banned Operetta Enyém az első csók - Minister of Interior May Allow Further Performances]. 8 Órai Újság. vol XIV issue 114 (20 May 1928) 9.

Lejátszották belügyminisztériumi bizottság előtt a betiltott Heltai-operettet. A bizottság döntését kedden hirdetik ki [Banned Heltai Operetta Performed in front of Ministry of Interior Committee. Decision to be Announced on Tuesday]. Magyar Hírlap. vol XXXVIII issue 115 (22 May 1928) 8.

Irodalmi törvényszék az Andrássy úti Színházban. Döntés: kedden délelőtt. [Literary Court in Andrássy Street Theatre. Decision on Tuesday]. Pesti Napló. vol LXXIX issue 115 (22 May 1928) 12-13.

Erkölcsbírák a nézőtéren. Két órán át vizsgáztatták az Enyém az első csókot, de nem határoztak [Morality Judges in the Audience. Enyém az elsó csók Examined for Two Hours but no Ruling Made]. Újság. vol IV issue 115 (22 May 1928) 11.

Módosításokkal engedélyezték a betiltott Heltai-operett előadását, de a belügyminiszter továbbra is helyesli a rendőrség eljárását [Performance of Banned Heltai Operetta Allowed after Some Alterations, but Minister of Interior Still Thinks Police Measures Were Right]. Esti Kurir. vol VI issue 116 (23 May 1928) 7.

Két mellékmondatot kellett kihúzni Heltai Jenő librettójából. Engedélyezték a további elöadásokat [Two Sub-clauses had to be Deleted from Jenő Heltai's Libretto. Further Performances Permitted]. Pesti Napló. vol LXXIX issue 116 (23 May 1928) 11.

Heltai-Szirmai Enyém az első csók operettének tüntető sikere az Andrássy úti Színházban [Demonstrative Success of Heltai-Szirmai Operetta Enyém az elsö csók in Andrássy Street Theatre]. Pesti Napló. vol LXXIX issue 119 (26 May 1928) 13.

Heltai-Szirmai Enyém az első csók operettének tüntető sikere az Andrássy úti Színházban. 8 Órai Újság. vol XIV issue 120 (27 May 1928) 10.

$\mathrm{Az}$ újra engedélyezett Enyém az elsö csók [Enyém az elsó csók Re-Authorized]. Esti Kurir. vol VI issue 125 (3 June 1928) 10.

Az újra engedélyezett Enyém az első csók. . Magyarság. vol XXXV issue 120 (27 May 1928) 12.

Az újra engedélyezett Enyém az elsö csók. Biller Irén - Rátkaival az Andrássy úti Színházban - A legdrágább jegy 6 pengö [Enyém az első csók Re-Permitted. Irén Biller with Rátkai in Andrássy Street Theatre -Most Expensive Tickets at 6 Pengö]. 8 Órai Újság, vol XIV issue 121 (30 May 1928) 11. 
Scitovszky belügyminiszter engedélyezte a betiltott Heltai-darab előadását [Minister of Interior Scitovszky Permits Performance of Heltai Play]. 8 Órai Újság. vol XIV issue 116 (23 May 1928) 12.

Két mellékmondatot kellett kihúzni Heltai Jenő librettójából. Engedélyezték a további előadásokat [Two Sub-Clauses Had to be Deleted from Jenő Heltai’s Libretto. Further Performances are Permitted]. Pesti Napló. vol LXXIX issue 116 (23 May 1928) 11.

Interpellációk [Interpellations], Pesti Hírlap. vol L issue 117 (24 May 1928) 8.

Minister of Interior Scitovszky Permits Performance of Heltai Play. 8 Órai Újság. vol XIV issue 116 (23 May 1928) 12.

A rendőrség betiltó rendelkezése miatt be akarta zárni kapuit az Andrássy úti Színház. Együttes akció készül az illetéktelen cenzúra ellen [Adrássy Street Theatre Wanting to Close Doors Due to Police Ban. Joint Action to be Launched Against the Unjustifiable Censorship]. Magyarország. vol XXXV issue 117 (24 May 1928) 9.

"Congress of Fine Arts and Literature to Demand End of Censorship in Theatres Decrease of police Fees and Entertainment Taxes." Az Est vol XIX issue 120 (27 May 1928) 12.

Az első magyar irodalmi és müvészeti kongresszus [The First Congress of Fine Arta and Literature]. Magyar Müvészet vol IV issue 3 (1928) 273-274.

Open Access. This is an open-access article distributed under the terms of the Creative Commons Attribution 4.0 International License (https://creativecommons.org/licenses/by/4.0/), which permits unrestricted use, distribution, and reproduction in any medium, provided the original author and source are credited, a link to the CC License is provided, and changes - if any - are indicated. (SID_1) 